\title{
What Future for Public Intellectuals?
}

The specialisation of knowledge, the commercialisation of culture and the emergence of post-modernism characterise China in the 1990s

Xu Jilin

\section{OpenEdition}

\section{Journals}

Édition électronique

URL : http://journals.openedition.org/chinaperspectives/799

DOI : 10.4000/chinaperspectives.799

ISSN : 1996-4617

Éditeur

Centre d'étude français sur la Chine contemporaine

\section{Édition imprimée}

Date de publication : 1 mars 2004

ISSN : 2070-3449

Référence électronique

Xu Jilin, «What Future for Public Intellectuals? », China Perspectives [En ligne], 52 | march-april 2004,

mis en ligne le 23 avril 2007, consulté le 28 octobre 2019. URL : http://journals.openedition.org/

chinaperspectives/799; DOI : 10.4000/chinaperspectives.799 


\section{What Future}

\section{for Public Intellectuals?}

The specialisation of knowledge, the commercialisation of culture and the emergence of post-modernism characterise China in the 1990s

\section{Xu Jilin}

W HILE THE QUESTION of the public intellectual has been the subject of lively debate in the
international intellectual community for over ten years, it has appeared in China only recently. What is a public intellectual? And why does this question generate debate? It is generally considered to be Russell Jacoby, in his book published in 1987, The Last Intellectuals, who called attention to the disappearance of the public intellectual. In his view, the intellectuals of the past, who wrote for cultivated readers, often had a public commitment (gonggongxing). In the United States, the generation born in the 1920 s is considered to be the last generation of public intellectuals. Actually, with the democratisation of university teaching, public intellectuals have been replaced by scientific experts and university professors, whose production is aimed exclusively at specialised readers. With the disappearance of public intellectuals, culture and public life also went into decline ${ }^{(1)}$. In France it is the passing of Jean-Paul Sartre and Michel Foucault that are generally considered as marking the end of the public intellectuals ${ }^{(2)}$. Let us first define what the term "public" means in the expression "public intellectuals". I believe that it carries three levels of meaning. Firstly, it designates a discourse aimed at the public. Secondly, it concerns thought carried out for the public, whose point of departure is the common good, rather than a personal position or individual interests. Lastly, it characterises the inclination for public affairs or major issues in society. These three levels of meaning contained in the notion of public commitment are closely bound to the conception intellectuals have of themselves. Now public commitment, which was initially one of the characteristics of intellectuals, is weakened today because of specialisation and the postmodernist movement. How can this commitment be restored in a specialised, post-modern society?

The question of the public intellectual is not only a Western problem, but also concerns China. In the 1990s, China experienced, as did Europe and the United State after the 1970s, a specialisation of the system of knowledge and the appearance of the post-modernist cultural movement. In this article I will firstly analyse the emegence of specialised intellectuals (zhuanye zhishifenzi) and of media intellectuals (meit zhishifenzi), two phenomena which are characteristic of China in the 1990s. Then, based on several debates devoted to the reconstruction of commitment which have taken place in the Chinese intellectual world, I will advance three ideal types: the traditional intellectual the organic intellectual, and the specific intellectual. Lastly, drawing my inspiration from Pierre Bourdieu, will analyse the possibility, in the era of specialisation, of constructing an ideal type of public intellectual, who from the specific, aims at the universal.

Specialised intellectuals and media intellectuals In China, the decade of the 1980s was very lively in terms of culture and public life ${ }^{(3)}$. The movement of liberation of thought at the beginning of the 1980s, folowed by the "cultural fever" (wenhua re) of the mid1980s (later called "The New Enlightenment" after the May 4th movement 1919), saw the appearance of group of renowned public intellectuals who reached a wide readership. These intellectuals were writers, scientists, philosophers, researchers in the humanities, sc even senior civil servants and ideologues of the sys an The subjects they broached all had a public dimsterion
Economic development and transformation of human capital

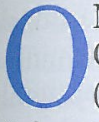
OCTOBER $27^{\text {in }}$ AND $28^{\text {th }} 2003$, the French Centre for Research on Contemporary China (CEFC) and the Shanghai Academy of Socia Sciences (SASS) jointly organised a conference entitled "Economic development and transformation of butions. What competences does China need today? How do individuals, as well as the training system adapt to the new demands of companies and of the administration? These were some of the questions asked and which the participants attempted to answer by exchanging their points of view on China, on Russia, another society and economy in transition, and on France; an approach based on the conviction that the social sciences can only be comparative.

The focal point of this conference was a consideration of the elites, a highly sensitive subject in a neo-authoritarian or neo-totalitarian communist regime. While certain actions of the new government team inaugurate a new phase in the policy of reform, which is more directed at those excluded from prosperity, does this really mean the beginning of a new practice of poicy and of politics, which must necessarily include reflection on-if not a calling into question of-those who are at the top of the social ladder? The session were organised around three subjects: the economic political and intellectual elites.

In his opening speech, Yin Jizuo ${ }^{(2)}$ recalled the context and the tenor of the changes experienced by the country's elites. China, in integrating itself into the world system by its policy of reform and opening up, has joined the scientific and technical revolution, bringing about the necessary adaptation of the Chinese working population, that is to say its professionalisation. This is particularly the case of company manarers, whose parte has evolved in order to respond to the neds of the transition. Shen Ronghua ${ }^{(3)}$ show to how the state enterprise managers, until then administrative state enterprise managers, until then adminisreal heads of superising production, have become of professional experience and competences validated by diplomas. It is not only enterprise mes validated have to adapt to the new economic environment, but to po a large extent, all employees, of whon specific coning the challenge of retraining their employes, Li Peilin and $\mathrm{Zh} \mathrm{Yi}^{(4)}$, basing themselves on, whom of surveys carried out in the province of Liaoning, showed would benefit from an effective system of professional training. Zhang Jiehal gave an example of successful retraining and of social mobility: that of migrant workers who have become white collar and thus identify with the urban middle class.

According to $\mathrm{Lu}$ Hanlong ${ }^{(6)}$, analogous transformations are taking place in the political sphere where the "reds" are making room for the "experts". Jean-Pierre Cabestan (i) confirmed this by studying a particular population, the delegates of the National People's Congress (NPC), the second most important group of leaders in China after the members of the Central Committee of the Party. The members of the NPC have an increasingly high level of education. Their legitimacy has been enhanced not because of the mode of election, but because of their increasing participation in debates which are more and more open to their growing expertise. What is true at a national level is also true, possibly even more so, at a local level. Li Yuomei ${ }^{(8)}$ underscored this by analysing the leaders of neighbourhood communities and other urban organisations, such as residents' committees or co-owners' associations; they are chosen more for their level of education or their professional status than for their links with the Communist Party. While in the eyes of these new social actors, professional competences are more useful and more valuable than membership of the Party, the same holds true for managing cadres who have themselves reduced ideology to a quasi-symbolic secondary importance. As our own work ${ }^{(9)}$ shows, the latter spend most of their training period in the Party schools or in the institutes of administration learning the stakes of the modern world and of post-Maoist Chin as well as training on more specific or technical questions, in order to carry out the new tasks imposed on them by ed on them by and opening up.

One could not tackle the problem of training for the leading elites without mentioning the French Ecole tionale d'administration (ENA) which inspired the Chinese government in the reform of its schools of administration and with which the latter maintain institutional and pedagogical links-their best students spend time in France. Jean-Pierre Worms ${ }^{(10)}$ sought to underline the distortions that "enarchy" has produced, in particular the de facto monopoly held by ENA graduates on positions of power in the economic and polit cal spheres. Thus, from the training of leading cadres the interrogation moved towards the problematical 
connections between the political and the economic, one of the challenges in the transition which are regularly brought up by the media during cases of corruption. Monique de Saint-Martin ${ }^{(1)}$ recalled that such connections also exist in Russia, where former Soviet bureauchas have beco rivate shareholders in large private enterprises after perestroika. Nevertheless, according to Marie Mendras the administrative apparatus in Russia has managed to tions in the political and economic spheres as well as the social one: in fact, at all levels of the country, years of upheaval have made the Russian administration stronger, and it is said today to be oblivious to political pressures.

To Zheng Yefu ${ }^{(13)}$, the remedy for the plague represented by corruption lies in a return to Confucianism and the placing of ethics and moral teaching at the heart of the pedagogical mission. Mao Hongxiang ${ }^{(1)}$ sought to show the glaring inadequacy of the Chinese education system, as a result of lack of investment and weak political will: urgent reform is called for. Finally professionalisation also affects the intellectuals-understood as the group of those with diplomas-who, according to Lu Xiaowen ${ }^{(15)}$, make up an essential part of the middle classes. Moreover Lu made an essentia distinction between the professional intellectuals, the academics and researchers who fulfil a function of experts for the governments, and the critical intellectuals. The latter recalled Xu Jilin (10), after having been very active in the 1980s, had great difficulty during the very active in the 1980s, had great difficulty during the decade of the 1900 in fly bate of a society which puts more value on expertise with a practical objective. Jean-P vilipe Beja , conparing China and France, went furcher, maintaining that the critical intellectuls, or counter-elites, are condemned to remaining in a minority and to seeing their role decline. Lastly Jacques Rupnik $k^{\left({ }^{6}\right)}$ showed how in certain Eastern European countries, the victory of the intellectuals (such as Vaclav Havel) also marked the beginning of their fall in the face of the advance of consumer society. As well as the question of the conversion of political capital into economic capital during the transition phase, he emphasised the importance of

and went beyond their spheres of specialisation whether political life, the comparison of Chinese an Western cultures, or the scientific Enlightenment. These "public intellectuals" gave lectures in the universities, and published articles in the newspapers and journals while their books were sold all over the country and eas- civil society in the consolidation of the democratic process.

The animated and open debates to which the body of these contributions gave rise were structured around the notions of effectiveness and equity. From the manager's point of view, the objective sought is an optima functioning of enterprises, administrations and the training apparatus. From the point of view of the citzen, it is access to education the conditions of promotion and of critical thinking which are questioned

Emilie Tran

1. This conference, which was held in Shanghai, could not have taken place without the financial support of the Consulate Ceneral of France in Shanghai, of the EGIDE programme of the
French Ministry of Foreign Affairs, and of the various institutiona French Ministry of Foreign Affairs, and hai our thanks to them at. The proceedings will be the object of a co-publication in ChiThe

President of the SASS

3. Shanghai Institute of Human Resources.

Institute of Sociology, China Academy of Social Sciences, Peking, for the former, and Institute of Demography and Labour Eco Institute of Sociology, SASS.

5. Director of the Institute of Sociology, SASS

7. Institute of Comparative Law, University Paris-I.

8. Shanghai University.

Emilie Tran, "From Senior Official to Top Civil Servant. An Enquiry into the Shanghai Party School
March-April 2003, pp. 27-40.

10. From the "France Initiative Network", Paris.

11. Centre for the Study of Social Movements, School of Higher Studies in the Social Sciences (EHESS), Paris.

12. Centre of International Studies (CERI), Paris

13. Sociology Department, People's University of China, Peking

14. Shanghai Institute of Educational Sciences.

Institute of Sociology, SASS

Department of History, East China Normal University, Shanghai. 17. Centre of International Studies (CERI), Paris 18. Centre of International Studies (CERI), Paris

ily reached print runs of tens or hundreds of thousands of copies. They had become influential public figures. China in the 1980s saw the emergence of a public cultural sphere, built around this core of intellectuals. It was endowed with several well-known journals, whic constituted a real space for opinion: Dushu (Reading)
Zouxiang weilai (Towards The Future), and Wenhuo: Zhongguo yu shijie (Culture: China and The World) Peking; Wenhui yuekan (Monthly Cultural Conpendium) and Shulin (Literary Forest) in Shanghai, well as Qingnian luntan (The Tribune of Youth) in Wuhan, etc. This network hinged on several groups of well-known intellectuals: the "scientists" represented by the journal Towards The Future, researchers in the humanities whose journal, Culture: China and The World was the leading light, and the supporters of the blending of cultures, represented by the Chinese Academy of Culture. Backed by a public of several million readers, this thre. Brce by the development in the 1980s, of an unspace fand cultural life, and formed a cultural field

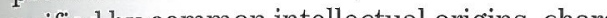
unified by corro con with the property of public critique, this space rese with the property of public critique, this space resembled the pere After the events of 1989, the situation changed eno mously. At the beginning of the 1900s, a considerable number of the most active intellectuals did not go into exile, but were constrained to silence in China. The most influential journals were banned, with the exception of the journal Dushu, the last vestige of a bygon era. Several groups of very active intellectuals, such as that of Towards The Future, led by Jin Guantao and tha of Culture: China and The World, directed by Gan Yang were obliged to disperse. Although, after the middle of the 1990s, the reform of the market economy allowe the opening of the economic and social spheres, and cit izens acquired more freedom in the private sphere in comparison with the previous decade, the spaces of freedom in the public sphere shrank. In short, in the 1990s, Chinese public intellectuals lost the political and social conditions which allowed them to exist: a public political sphere with a genuine atmosphere of freedom. The disappearance of public intellectuals in 1990 China was also linked to the profound differences which appeared in their midst. In the camp of the "Enlightenment" of the 1980s, despite different sensibilities (for example Towards The Future represented the scientific movement and Culture: China and The World brought together the adherents to the humanist movemert), the cultural and political trends were identical: when the criticised traditional Chinese culture, when they stues Western culture, or chinese culture, when they studied system of Maost or when they opposed the totalitarian democratic Maist socialism by introducing the idea of United States, frem, borrowed from Europe and the same States, their positions and attitudes were the ame. But from the middle of the $1990 \mathrm{~s}$, with the emerthe inte market society, there appeared a deep rift in society society and on the direction of reform. The lively contro- versy between the liberals and the new left merely crysallised the divergences. These manifested themselves not only in the field of ideas, but also on the level of nowledge and personal relations. At the end of the 1990s, public journals and intellectual groups expenenced an entirely new situation of enforced allegiance Beyond these factors, however, the disappearance of public debate is more fundamentally linked to the specialisation of systems of knowledge and to the commercialisation of intellectual production. With the increasing of state investment in education, the universities have, in the last few years, experienced major growth, not only in the numbers of students and in the range teaching but also on the level of managemt range of The production and disseming of caried out on the bas of a igid systen of divion of disciplines, and the professors' results are now evaluated according to strict norms. The grow are now evaluated according to strict norns. The growth in the state system and the race for profl have encouraged a large number of intellectuals, once active in the public sphere, to join the university system and hire out their services. However, cloistered in the university, they can no longer pursue their reflection, or write and publis from their own areas of interest. Subjected to the specialisation of their discipline, they are the authors of highly specialised intellectual products, the objective of which is the progressive accumulation of scientific capital, and the recognition of specialised authority.

This trend towards academic specialisation has produced a double rift. On the one hand, what was once unified field of knowledge has divided into a multiplicity of specialised domains like the cells of a beehive: between the possessors of knowledge in different disciplines there are no longer any language, debating space or knowledge objectives in common. On the other hand with specialised intellectuals addressing their peers an turning their backs on the public the organic links which once conted them to the public havic lin. brok they have become once agin a che been broken: they have be

But what of the intellectuals who have remained out side the system of knowledge? With the growth in the market from the middle of the 1990s, the production of culture has become similar to that of other consumer goods. Where once they answered to a sacred mission or to the desire for self-expression, intellectuals are now summoned by the market to produce according to the desires of cultural consumers, with the dissemination and distribution of cultural goods following the laws of the market. The shrinking of cultural space, the rise of mass culture, as well as the increase in the leisure time and consumption capacity of the public, have obliged publishers, newspapers and leisure magazines to provide 
more cultural consumer product. It is on this fertile ground that media intellectuals of various kinds have appeared: writers, experts, professors of the humanities, etc. In appearance, they are scarcely different from the former public intellectuals: aiming at the general public, they sometimes intervene, in the midst of their endless they sometimes intervene, in the midst of their endless
and tiresome buffoonery, on highly serious subjects. And and tiresome buffoonery, on highly serious subjects. And yet the difference between media intellectuals and pub-
lic intellectuals is clear: during public debates, the forlic intellectuals is clear: during public debates, the former do not conform to what they personally consider to be a public position, but rather to the hidden logic of the market. When they resort to criticism, they are really acting under the impulse of commercial interests, and anticipating the desires of the market.

At first glance, these two trends seem to lead to a polarised situation: the specialisation of knowledge is indeed far from the market, the opposite of the commercialisation of culture. But closer examination reveals that both these developments are dominated by the laws of instrumental rationality. In the field of the production of knowledge, the transcendental capacity that knowledge once had has been destroyed: it no longer produces meaning for the whole of society and the world, and has been fragmented into numerous domains. With no relation between them, the meaning produced is only revealed in a series of objectives or concrete instrumental relations. This technical understanding of knowledge has produced a large number of experts. Cloistered in has produced a large number of experts. Cloistered in
university life, some of them, in answer to solicitation, university life, some of them, in answer to solicitation,
appear frequently in the media to debate so-called pubappear frequently in the media to debate so-called pub-
lic affairs. However, in contrast with the intellectuals of lic affairs. However, in contrast with the intellectuals of
the past, the experts have abandoned transcendental the past, the experts have abandoned transcendental and utopian values. Their public engagement no longer comprises any critical reflection. Accustomed to intervening from a technical level, their ability to examine
their own errors or to debate public affairs is inadequate. They deal with political and public questions from a management point of view, and all subjects seem to be soluble with the help of technocratic instrumentalist rationality.

To sum up, after 1989 and the events of the 4th of June, the group of public intellectuals, who had considerable influence and had criticl capacities, was replaced by two oth categories of individuals who were active in the mer the tecticine in the mity world. Under the strange combins of the unistate wstem and the logic of the corket, Chin in the state system and the logic of the market, China in the $1990 s$ was chacterised by the disappearance on the one hand of a serious and critical public sphere, and on the other by the unprecedented opening of an artificial public life. For the dommant media, the media intellectuals who serve the logic of the market, as well as the specialised intellectuals who provide their technical ex- pertise, are a godsend. It is in these exchanges between technical experts and media stars that the official ideology is formed, the main ingredients of which are specialisation and commercialisation.

The attempt to rebuild a public commitment The disappearance of the public intellectual in China in the 1990s is also linked, to a certain extent, to the assessment of the 1980s made a posteriori by the intellectuals, and to their conscious and rational choices made in their new environment. While the social changes we have referred to appeared only at the end of the 1990 s the various intellectual debates which followed one another at the beginning of the decade already testified to a withdrawal of the intellectuals from the public sphere and a retreat to their spheres of specialisation. This retreat, however, was not dictated by short-term tactical calculation, but testified rather to a strategic retreat, guided by rational introspection

The first debate in the intellectual world in the decade of the 1990s focused on the history of science (xueshu lishi) and its norms (xueshu guifan). In January 1991, group of intellectuals in Peking organised a conference on the theme of "research on the history of science". summary of the conference was then published in an (the This jebte This debate was situated in the context and spirt of post-1089. the intellectuals were seized with uncertainty, and everyone was wondering bitterly what should be done, and what it was possible to do. Some of the intellectuals, engaged in a reflection on cultural life in the 1980 s, called for a return to science, and a reconstruction of its norms. Chen Pingyuan, one of the main writers of the journal Xueren, is representative of this position: while the 1980s were "a period filled with enthusiasm and imagination", the questions of the intellectuals were steeped in a scientific atmosphere which was "light" and "dispersed". They "introduced many [new ideas] but did little research, their creativity was great but their connection with reality was weak". In his view "The decade of the 1990s may have a greater need for constraining scientific norms which, through a series of scarcely poetic procedural operations, will attempt to transform 'the spark of thought' previously produced into scientific results. This trend towards growing specialisation will be a tough test for those in the university who lack the academic training necessary, base themwher selves only on common sense, and ask questions wher-
ever their inspiration carries them" (5)

This article in the journal Xueren, republished in the unofficial journal Zhongguo shuping, (Chinese Inventoeditors were from Hong Kong, opened the way to a

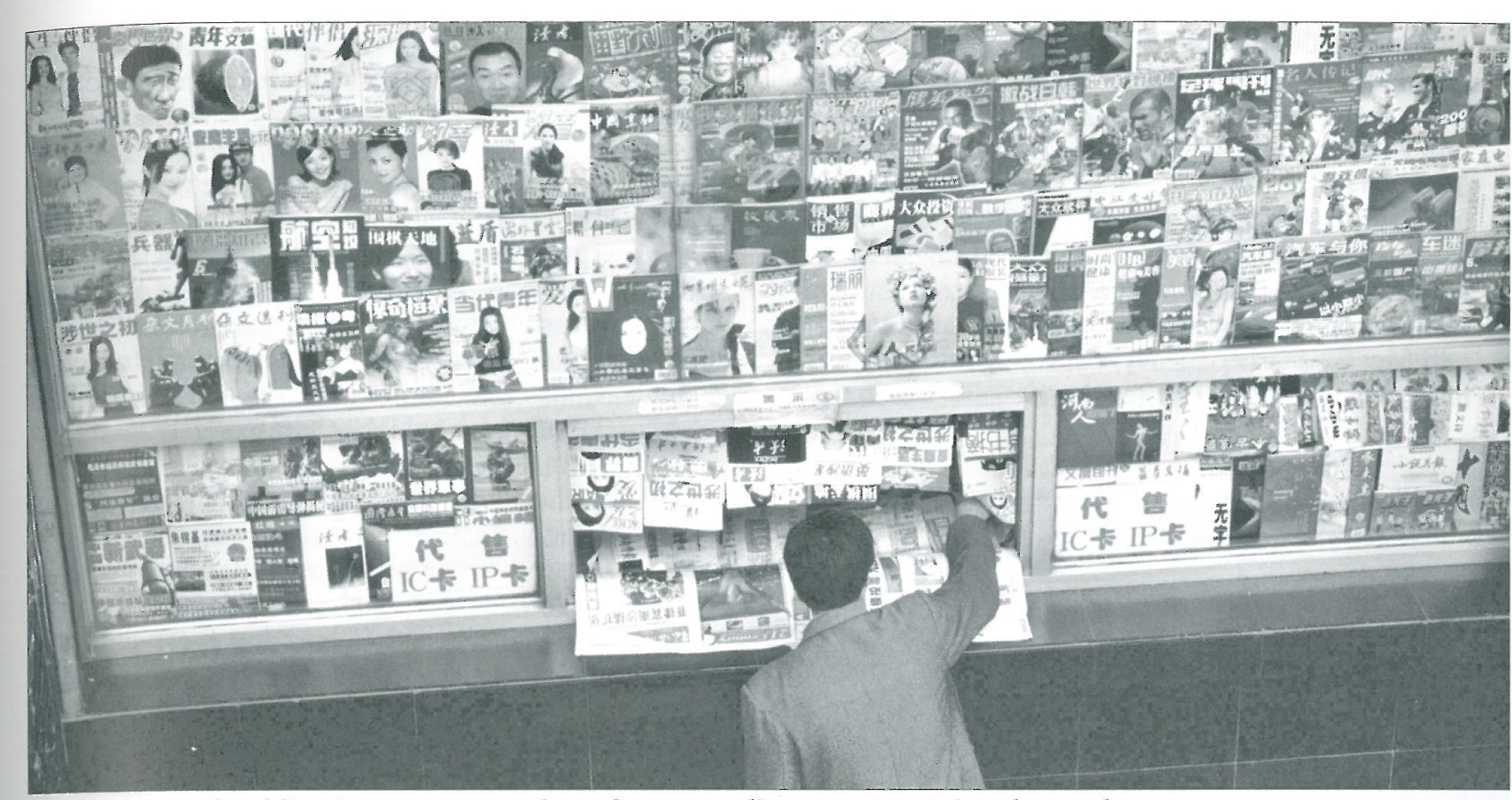

No shortage of publications as mass culture forces media to meet soaring demand

major debate about academic norms. This debate contributed to an important change in the conception intellectuals had of their role. The space occupied by intellectuals was no longer the public square, but rather a specialised sphere and a field of competences. It was what Chen Sihe and others have called a "sense of the profession" (zhigang yishi) ${ }^{(6)}$

To this group of intellectuals who were very active in the 1980 s, the profession was not only a job, but rathe a way of reviving the values of life and of specialised orentations. In the 1980s, Chinese intellectuals were fille with what Max Weber called "grace" or a sense of mission: aware of adversity, and worried about the destin of the nation and the people, they were always ready to follow the call of a sacred mission, to sacrifice themselves in order to awaken the people and help the nation. In the 1990s, this "grace" was replaced by what Max Weber called "vocation" (ग). This shift from grace to vocation, from an enchanted world to its disenchantment, is the expression of a major change in the spirit of the intellectuals. With the falling-away of the sacred, the teleological vision of the cosmos, once filled with meaning, came apart completely, and the world shattered into infinitesimal mechanical fragments.

The intellectuals wanted to find a meaning to life: with only one objective left at their disposal, they found it within their fields of competence. Some of the intellectuals of the 1980 s, after having again pondered over their mission, aspired to this vocation, to returning to the university, and to throwing themselves into their specialisation. This strategic retreat took place at the tude and of loss produced by the commercialisation of the university, they relied on their spirit of vocation in A more wide-ranging debate, focusing on the humanist spirit, took place from 1993. This debate was linked to the sudden eruption of the market society and to the marginalisation of the intellectuals. In 1992, after Deng Xiaoping's journey through the south, the market economy hit China like a storm: mass consumer culture replaced the elitist culture of the intellectuals in the forefront of the public scene. In the 1980 s, when the transformation of society was concentrated in the domain of ideology, public intellectuals were at the centre of public attention. After 1992, however, under the pressure of the market economy, a swiftly disenchanted society moved away from ideology, thereby marginalising the intellectuals.

Chen Pingyuan in Peking and Wang Xiaoming in Shanghai were the first to have a premonition of this problem. The articles they published in 1993 tackled it with a reflection on the decline of the elite culture and the disappearance of literature from humanist preoccupations. But each had a different attitude. Chen Pingyuan was als being able only to return to the sciences and to sink beginning of the 1990s: experiencing a feeling of soliorder to withstand marginalisation and pauperisation. conscious that the decline of elite culture was a histori- 
into marginalisation ${ }^{(8)}$. Wang Xiaoming, for his part, attempted to shoulder the burden of the crisis by calling on the humanist spirit once again, and by using a new attitude to return towards the public ${ }^{(\theta)}$. That year he brought together other Shanghai intellectuals to publish in the together other Shanghai intellectuals to publish in the journal Dushu a major debate devoted to the humanist spirit. Among the many points discussed, one of the most important raised the question of relations between the intellectuals and society, after the marginalisation of the larly on the separation, after the 1990s, between the in-

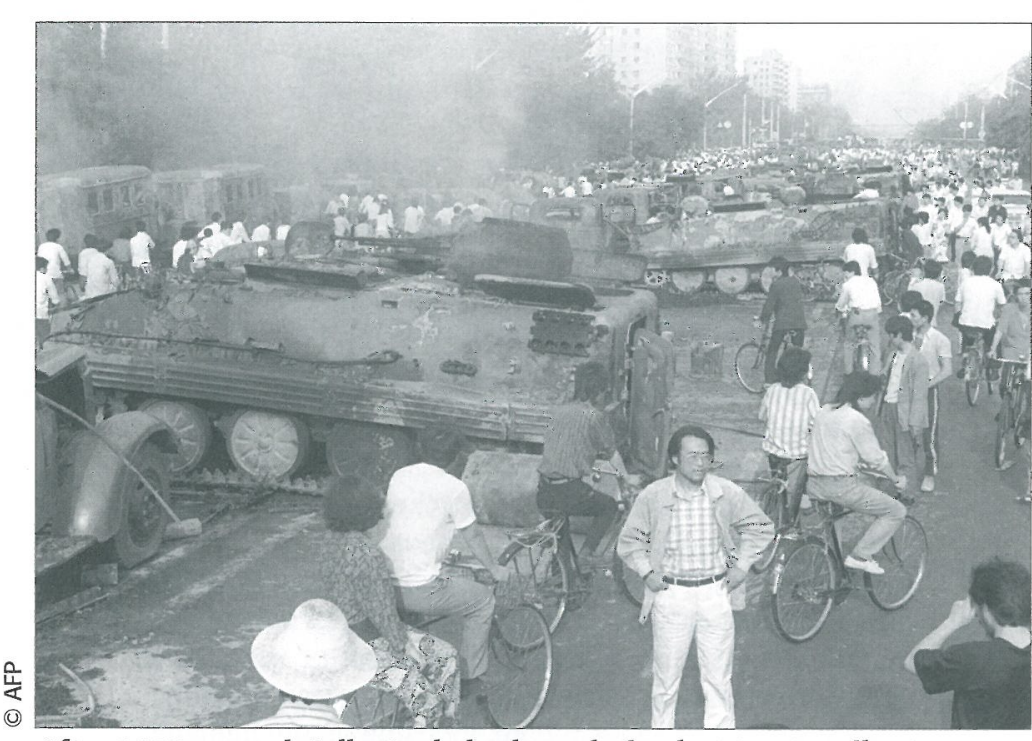

After 1989 many intellectuals had no choice but to stay sillent

tellectuals bearing the Enlightenment and the general public, which is the object of the Enlightenment: "The public is the master of its interest in the economy, it seeks to satisfy the needs of its five senses, and rejects the 'tireless teaching' of the intellectuals. The bell has rung for the end of class, the intellectuals' role as 'spiritual advisors' has already vanished."

To these intellectuals, the very rapid secularisation of China deformed and, devoid of any emotion, made a mockery of the aims of existence and the ideals which they had worked to establish. The sense of a sacred destiny, of a tragic consciousness, and of the ultimate ideals which they allowed themselves, evaporated in an instant. "Only the questioning of the vanity of their intellectual elitism can make it possible for them to define themselves anew" (11). And yet, introspection or of the humanist spirit of the attempt to rebuild the public encer again the responsibility for guiding society. Howeve while at that time the humanist spirit still retained a sa- cred aura, strong opposition had arisen, calling into question its ability to define the role and values of the intellectua

More fundamentally, among the defenders of the humanist spirit themselves, no consensus had been reached about the down-to-earth definition of this spirit These divisions testify to the impossibility, in the 1990 of creating a concrete objective and a belief in a common commitment: not only had the gulf between the intellectuals and the public widened, but the intellectual community had lost the "common posture" (taidu de tongyixing) which characterised it in the 1980s. In order to avoid an interminable debate on the question of the interpretation of the humanist spirit, the author put forward at that time a negative definition of it: it is only possible to make a common assertion of what it is not. As for its certain meaning, it can only be a formal moral principle, in the manner of Kant who posited "Man as the end". Its concrete meaning and interpretation therefore depend on the framework of cultural values and the historical situations of enunciation in which it is inscribed ${ }^{(12)}$. In the situation of increasing division of values within the intellectual community, only a formalisation of norms could make nity, only a fos malistion of norms could make it possible to re

Zhang Yiwu and Chen Xiaoming called attention to the fact that the humanist spirit is not only a mode of intellectual narrative, a sort of "great narrative" as Jean-François Lyotard used to say, but also, to quote their words the "last sacred word of the new post- (modernist and colonialist) period (1). It seems that it was in order to compete with the debate about the humanist spirit that these two intellectuals, later nicknamed "Master Zhang of post-" and "Master Chen of post-", launched a debate in 1994 on postmodern and post-colonial culture. Their objective was the opposite of the humanist spirit intellectuals: it was not a question of reconstructing a set of words and values common to the public intellectuals, but indeed, based on post-modernist and post-colonial critical theory, of destroying the last bastion of the public intellectuals: the vanity of public speech. As they saw it, since the May 4th movement of 1919, Chinese intellectuals had constructed a number of "great narratives", which had modernity at their heart This narrative mode used Western discourse as its only reference, and was tinged with colonialism. Relying on this body of discourse imported from abroad, Chinese intellectuals posed as stimulators and spokesmen of the Enlightenment as the only project managers of the knowledge/power of modernity.
Beginning in the 1990s, China, having entered "the new post- era", was marked by three developments: the exposttension of the aesthetic judgement, and the pluralisation of cultural values. This new phase marked the collapse of culcerity constructed on reference to the West of a modernity constructed on reference to the West, and announced the passing of those inte" (1) The iflubased themselves on the "great narratives". The influence of the post-modern studies movement was far inferior to the demands of the humanist spirit. Its supporters were determined to construct another "great narrative" which would replace that of modernity: "sinity" (15). However, they were forerunners in the introduction of post-modernity in China. The works of JeanFrançois Lyotard, Michel Foucault and Jacques Derrida, representatives of French post-modern theory, were translated and commented on. In the second half of the 1990s, the critique of the idealism born of the Enlightenment movement led to the deconstruction of the foundations of the traditional public intellectual.

During the 1990s, post-modern language and scientific specialisation gradually emerged as the dominant intelsptual phenomena At the end of the decade the disaplectual po the public commitment of the intellecturs peas an unquestionable objective fact The intellectual was an or community experienced a profound internal differentiation. Some sphere, while others tried to restore the organic relations between knowledge and public life. Moreover, among the public intellectuals themselves, there emerged divergences about how to rebuild a form of commitment . It focused principally on the understanding that intellectuals had of themselves and the context in which they were situated. Three types can be distinguished.

The intellectuals of the humanist spirit movement were convinced that they embodied universal truth, intuitive knowledge and justice, sacred values in the name or which they were bound to struggle and to intervene in society. They emphasised in particular that, while the practice of the humanist spirit remained individual, its foundations rested immutably on "universal principles which transcend the individual". Nihilism and cynicism are not tolerated in this model. The humanist spirit is an attention which is inseparab from practice, and which testifies in itself to the consciousness of human practice In its opposition to the coms of histipn of society. the humanist movement made up principally of researchers, seems relatively moderate, compaly of remoral idealism movatared to the as Zhang Chenghi and Zhong Wei, this by writers such on the contrary and Zhang Wei, this group displayed, face of the secularisation of society, the Zhangs launched the pretentious slogan "Resist Surrender". Calling themselves "Spiritual Saints", they declared that the flag of resistance and refusal to compromise launched by Lu Xun, must be raised high. It was a question of representing the popular masses, the oppressed the underprivileged and the marginalised, of "challen ing the Chinese intellectual world, which has long been separated from the masses, and which constantly turn its back on the people", of "smashing or resisting literature and the sciences which have been transformed into systems". In order to resist, they had no hesitation in praising violence ${ }^{(18)}$

The "critical intellectuals" appeared later, from the middle of the 1990s. Drawing inspiration from the post modern and post-colonial movements, Wang Hui casts doubt on the universalising modernity of the Enlightenment. He worries about the loss of organic connection between the intellectuals and public life, because of the effects of university life, and focuses his attention on the control exercised by the market on the public sphere. In his view, the main responsibility of the intellectuals lies in the revelation of hidden power relations. Rejecting the label "new left", Wang Hui uses the name "critical in tellectuals" to designate the characteristics of the intelectuals he represented: "The feature common to the critical reflection group is that they are devoted to revealing the relations between the political and the economic to revealing the internal links between the ways of thinking to which the intellectuals are accustomed and the inegalitarian process of development"

These three types of intellectual are not a phenomeno specific to Chinese experience, but represent respectively three classic ideal types of intellectual: the tradtional intellectual, the organic intellectual, and the specific intellectual. The traditional intellectual and the specific intellectual correspond to the classic distinction be tween intellectuals made by Antonio Gramsci. The traditional intellectual conceives himself as being independent and autonomous. Transcending the interests of society and of groups, he represents truth, justice and the ideal which are common to a society. Organic intellectuals are attached to social classes: there are organic relations between them, the social system, an interest group or a class, of which they make themselves the spokesmen ${ }^{(20)}$. The specific intellectual, a concept developed by Michel Foucault, is in opposition to the universal intellectual. To Foucault, the traditional intellectual and the organic intellectual both belong to the category of the universal intellectual, in particular because of their belief in the existence of universal truth and knowledge, bu also because, playing the role of prophets with conviclectual is precisely the antithesis of the universal intel- 
lectual: he makes no prophecies and does not commit himself to any social objective. It is only based on the position he occupies, and by a specialised mode of analysis,
that he reveals all that is inseparable between truth and power, and destroys the power relations concealed by society. He therefore defines himself by criticism, but by concrete criticism, rather than by a total construction In China in the 1990s, the humanist spirit intellectuals particularly displayed characteristics of the traditional intellectual, the proponents of moral idealism belonged to the category of the organic intellectuals, while the critical intellectuals were closer to the specific intellectuals of the Foucaldian type ${ }^{(22)}$

\section{The vanity of the universal intellectual}

What is a universal intellectual? Jean-François Lyotard in a well-known article, "The tomb of the intellectual", described him as follows: "Intellectuals' are rather, it seems to me, people who, putting themselves in the place of man, of humanity, of the nation, of the people, of the proletariat, of the creature or of some such entity, that is to say identifying with a subject endowed with a universal value, describe and analyse from that point of view a situation or a condition and prescribe what must be done for this subject to be realised or at least for its realisation to progress. 'Intellectuals' address themselves to each of us in so far as he is the possessor, the embryo, of this entity, their declarations refer to him to the same extent, and similarly proceed from him. The responsibility of the 'intellectual' is inseparable from the (shared) idea of a universal subject. It alone can bestow on Voltaire, on Zola, on Péguy, on Sartre (to mention only France) the authority which was recognised in them." (2) The universal intellectual is historically composed of two types: the traditional intellectual and the organic intwollectual. Often freelance, traditional intellectuals do not depend on any system, whether commercial, cogninot depend on any syster, whe from the point, cogntive or tatection of their identity, llke fre elctrons of a bohentan spirit. Traditional intellectuals believe they embody universa reason, justice and the ideal. The French writer Emile Zola is the very model of this. Th the Dreyfus affair, with his "J'accuse", he rose in indignation and marked the birth of the modern intellectual. In their collective petition, the intellectuals were not protesting only in the name of Dreyfus' innocence, but were also fighting to protect the truth and justice of the whole of society ${ }^{(24)}$ The traditional intellectual is the original form of the modern intellectual: just as a man's childhood determines his destiny, so the traditional intellectual has bequeathe to intellectuals, as common emblems, the thirst for freedom, sensitivity, a highly developed sense of justice, and the courage necessary for social criticism. And yet, can intellectuals continue to use the traditional mode in order to exist in a context of intensive specialisation of knowl

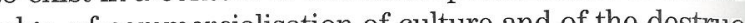
ion of original language by post-modern society?

Karl Mannheim distinguished two forms of knowledge possessed by intellectuals: knowledge derived from day to-day experience and esoteric knowledge ${ }^{(25)}$. Taking as a framework day-to-day and esoteric knowledge, modern intellectuals have built two models, the university intellectual and the media intellectual. The university intellectual is in the grip of the rules of specialised knowledge, while the media intellectual undergoes the control of the commercial logic of the media and the publishing houses. In contemporary China, these two types of intellectuals are described as intellectuals inside the system (of knowledge) and intellectuals outside the system (of knowledge). This distinction, initiated by the intellectuals outside the system, is rejected by those inside the system, because of the implicit normative judge ment which it entails. To the intellectuals outside the system their colleagues inside have already lost their critical col the of the aniversity. The in ar said to resenthe ing of the past. they are independent, whout any ties, and have a strong capacity for resistance. However, while the university intellectuals have lost the possibility of commitment and a critical spirit, should one conclude that all the unofficial resources are synonymous with freedom, reflection and criticism? Can the traditional intellectuals continue to exist outside the system?

As we have already pointed out, contemporary society, in particular outside the state system, has long ceased to be a haven of liberty. The laws of the market control the media and the publishers who produce and disseminate culture. Even unofficial journals and publishers are no exception. After the withdrawal of many intellectuals to the bosom of the university, the public sphere was invested by the media intellectuals who are either members of the media or freelance individuals who live by selling their talents. They possess neither the status nor the wisdom of $Z$ ala nor the specialised competence in philosophy of Sartre: "They ask television to give then phe fame that in the past, only an often obscure lifetime the fame that, in the past, only an often obscure lifetime of reseach and of work could confer. They conserve only the external signs of the intellectuals role [... Since they take positions on all the problems of the moment without any critical consciousness, without an technical competence and without any ethical convic tion, they are almost always in agreement with the established order" (26).

Even more threatening is the encouragement given by the media and the cultural businesses to criticism
Under an authoritarian political regime such as that in China, heterodox voices are a rare commodity which can be highly lucrative. Big risks generate big profits, and the possessors of capital, in the search for profits, are prepared to take such risks. Under the domination of the laws of the market, heterodox voices are constantly incited to free themselves: the more radical and extreme they are, the more they are encouraged, and the more they win audiences, visitors on the Internet, and increasing print runs. Funnelled through the input-output system of capitalism in this way, they turn into real commercial profits. Under the invisible control of the market, unofficial intellectuals, without realising it, then als, whout realising it, then lose their critical position. If traditional intellectuals dared to confront the reason of state, it was because the were profoundly convinced that they possessed and represented a higher reason. In modern society, which is more and more differentiated and whose knowledge is more and more specific, is does the the sill exist, or even metaphysical knowledge? This point has been called This point has been

The late writer Wang Xiaobo, known for his love of learning and of reason, abwho thought they represented the omniscient truth revelled in empty words, and harmed the state an the people. In the preface of

his collection of essays, by

he of introduction, he tells the following story. When made a strong impression Shaw's play Major Barbara on seeing his son for the first time in several years, asks him what interests him in life. The son, who has absolutely no knowledge of science, art or law, asserts that he has the ability to distinguish between the true and the false. At these words, the father bursts out laughing and makes fun of his son: "That kind of thing, even scientists, politicians and philosophers find difficult: you who don't know how to do anything you can tell the tho from the false?" Wang Xinyol that passage he said to himself in distress: "You can do anything in this life, but you must not become an incompetent who only knows how to distinguish the true from the false" (28). When he wrote this passage, in the middle of the 1990s, Wang Xiaobo was already aware of the dangers which threatened the intellectuals. He had seen too many intellectuals, completely lacking in analysis and reflection, busy pouring out a stream of empty words in the media. They excelled in giving their opinion on any subject whatsoever. These stars of academic culture are to be found in China as well as in the West ${ }^{(29)}$. In Émile Zola's time, society was not yet so complex and knowledge so differentiated. There were many tra- ditional intellectuals with multiple talents who could go byond their various domains to express themselves in ociety. Nowadays, however, a critique based not on would have great difficulty in competing with the experts. The latter can indeed cover facts and judgements with all sorts of technical arguments. In the face of the competence, have no way of convincing the public of the credibility of what they say.

Some traditional intellectuals reverse this argument: in the case of many social problems one must base oneself on the common knowledge of everyday life, and on 
one's intuitive knowledge, in order to be able to tell the true from the false! This is why Wang Xiaobo used to say bitingly: "Someone who knows only how to tell the true from the false depends always on the extreme probity of their own brain, and even adds, 'Isn't that self-evident?' Now anybody who has a basic training in science knows that, in this world, there is simply nothing which is self-evident" ${ }^{300}$.

Common knowledge does not exist objectively, but is the fruit of a long historical accumulation. Common sense can only play a legitimate role in societies whose development is slow, such as the traditional societies of the past. At a time when the world is experiencing rapid change, there are many problems which go beyond this field. As for intuitive knowledge, it is a judgement which belongs to the field of morality. Like common sense, morality is not self-evident. Asserting that only intellectuals possess a moral and political sensibility, and that the ordinary citizen lacks moral intuition, has no foundation and is merely ridiculous arrogance. In the course of many major historical events, the popular masses have not only equalled the intellectual elite in the moral practice of justice, but have even surpassed them by their courage and intrepidness. What society expects from the intellectual is not only the moral practice of the citizen, it is above all the reflexivity based on reason, the capacity to question the whole of the unjust relations between order and power, and to produce a legitions critique. This critique cannot be built on ordinary and general knowledge cannot be built on ordinary and it must begin in a or on a base of it must begin in a persed knowledge.
cialised

Among the universal intellectuals, next to the todiAmong the universal intellectuals, next to the traditional intellectuals, are the organic intellectuals. They share a belief in the existence of a universal truth. They tice. But while the traditionel intellectuls firmly beliesthey are free and detached from reality and can reve they are free and detached from reality, and can raise interest interest, on the contrary, the organic intellectuals consider that in a society divided into classes, intellectual cannot separate themselves from various interes groups. Always representing the voice of one class or another, the organic intellectuals must discern whic class embodies the future of history. Taking on the destiny of saviours of the world, they must fulfil the role of spokesmen for this advanced class. The Jean-Paul Sartre of the post-war period belongs in a sense to thi group ${ }^{(31)}$

Now this consciousness among the organic intellectuals, of being the spokesmen for the masses, is exactly what Pierre Bourdieu designates as an illusory myth This myth makes the intellectuals into fellow travellers of the "universal classes". However, to Bourdieu, it i not the "universal classes" which determine the intellectuals, but the intellectuals who determine the intellectals, always considering themselves to be the suprem judges of universality ${ }^{(32)}$. Lyotard also expressed thi
idea, in his critique of Sartre ${ }^{(33)}$.

Organic intellectuals are often inclined to populism embellishing in an abstract manner the just and mor sentiments of the people. And yet, when the real people are evoked, they show contempt and lack of trust, and consider that the people cannot express themselves alone or be their own representatives. To Michel Foucault, the organic intellectuals secretly participate in the mechanisms of power which prevent the people from expressing themselves. Foucault considers that the rea role of intellectuals is not to make themselves the spokesmen for the masses, but to fight against the existing forms of power, and to reveal the hidden relation between the language of knowledge and the domination of power ${ }^{(3)}$

In the contemporary West, the organic intellectuals who, in the manner of Sartre, pin their hopes on lare scale movements and total objectives, are in decline. tellectuals have begun to associate with in decline. Inion movements, such as the feminist movement (the feminist movement, the movement, the ecological movement, etc. These outward of a new kind are polymorphous in their asting expression. They are incapable of creatin ideology which could bring ton, and lack a unifie movements around it bring together all the groups and cose intellectuals have

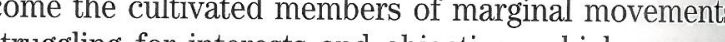
crugging for interests and objectives which are con-
crtial. Treditions and

Traditional and organic intellectuals, in their position s universal intellectuals in Foucault's sense of the term all have an urgent sense of mission: it is a question folowing the call of reason, of truth, of justice, of intuitive or class knowledge, and of struggling in the name of the acred mission to save humanity. But when specialised domination dissolves the enchantment of a mission, where do the intellectuals stand? And how will they intervene in the public sphere?

The specific intellectuals, a model of commitment? Michel Foucault introduced the concept of the specific intellectual, in contrast to the universal intellectual While the universal intellectuals are men of letters, the specific intellectuals are experts, or researchers, ben on deconstructing total power in their concrete domains. Foucault himself can be considered as the model of the specific intellectual. Firstly, he refused to define himself as an intellectual: "The word intellectual seems strange to me. I have never met any intellectuals. [... On the other hand, I have met many people who tal about the intellectual". The intellectual does not exist in real life, there are only concrete intellectuals, for example writers who write novels, musicians who compose, professors who teach, or experts in economics. They are the ones that Foucault calls specific intellectuals Specific intellectuals call universality into question time ${ }^{377}$. If they have inherited the historical tradition of the universal intellectuals, it is in their critical faculties. Yet, while universal intellectuals and specific intellectuals have in common the critique of power, the critique of the specific intellectual differs strongly from that of the former. To the specific intellectual, truth and power are former. To the specind all power lies a language system inseparable. Behind all power lies a language system producer of knowledge and truth, is situated at the heart of power ${ }^{(38)}$.

The rebellion of the specific intellectuals against powe rebellion of the specific intellectuals against power does not aim the destruction of all the prohibitions concerning desire and individual develop tions con arder to own life according to his wishes. Yet what individual own life according to his wishes. Yet what individual freedom acheves cannot transcend a concrete situation. It always neds con free, equitable and fair. Men who desire freedom and set out on the path to freedom must answer this question: how is individual freedom possible? What social conditions must we fulfil in order to achieve individual freedom? As Albert Camus rightly said, rebels must not only know how to say no, they must also know how to say yes, to the certain existence of universal justice. That is the only form of rebellion which has value. But Foucault is only ready to say no, and rejects the existence of a
universal value of public justice. In this way, he falls into universal value of public justice. In this way, he falls into
the same trap as nihilism: by denying the certainty of individual freedom, he denies himself.

Jürgen Habermas criticised Foucault thus: "Foucault did not fully think through the difficulty, from a methodological point of view, of his position. He did not see tha his theory of power would meet a fate similar to that of the humanities, rooted in the philosophy of the subject His theory strove to transcend these false sciences and to achieve a sterner objectivity. But it is precisely for these reasons, and with even less recourse, that it fell into the trap of a history of the present time. With his eyes wide open, he saw himself being pushed towards a relativist self-denial, and was unable to provide the least explanation concerning the normative foundations of his language." (39) The specific intellectuals, embodied by Foucault, base themselves on the strength of tions. They constitute a subversive potential in the opruction of unjust social orders. But these critiques do not in themselves have any means of building a just society instead, and even risk disintegrating public life. Moreover, by rejecting any objective of value, specific intellectuals lead to the splitting up of individual resistances; resistances which cancel each other out and have no way of competing with the system of total power, thus losing the effectiveness of criticism.

From the specific to the universal

The commitment of the universal intellectual seems to be more and more vain, and the specific intellectual has no way of constructing a new form of commitment. Is there an escape from this dead end? We maintain that, in a post-modern society, inasmuch as we need a public life, universal values remain essential. Opposition based on specific domains can neither constitute a global force, nor rebuild a public commitment. With the intensive specialisation of knowledge, intellectuals whose critique is based on universal values alone represent only a futile force, which lacks effectiveness. Is it no possible to escape from the dead end between the universal and the specific, and to construct an ideal type of the public intellectual who from the specific attains the divi, I will try to mselre on the theory of Piene Bourdieu, I will try to outline an ideal type of the public intellectual, who from the specific, reaches the universal. In an article published in 1989, "The corporatism of the universal: the role of the intellectuals in the modern world", Bourdieu deals in a detailed manner with the possibilities for the intellectuals of the whole world of reaching the universal from the specific, and of intervening in the problems of society while protecting the autonomy of their knowledge. This is precisely the central question ${ }^{(4)}$

Bourdieu asserts that the intellectual exists in a contradictory manner or according to two dimensions: he is both purity and commitment. A cultural producer who wishes to become an intellectual must then fulfil two conditions: "The intellectual is a two-dimensional individual who exists and subsists as such if (and only if) he is invested with a specific authority, conferred by an autonomous intellectual world (which is to say independent from the religious, political, or economic powers) whose specific laws he obeys, and if (and only if) he commits this specific authority to political struggle. Far from there being, as is usually believed, a contradiction between the search for autonomy (which characterises the art, science or literature which are called 'pure') and the search for political effectiveness, it is by increasing their autor polical efectiveness, it is by increasing 
7. On vocation, see Max Weber, in Politics as a Vocation, translated by Feng Keli, Beijing sanlian shudian, 1998. Qian Yongxiang has
made a close analysis of the sense of vocation in Weber, see his made a close analysis of the sense of vocation in Weber, see his
article: "Zai zongyu yu xuwu zhishang" (Above pleasure and notharticle: "Zai zongyu yu xuwu zhishang" (Above pleasure and noth-
ingness), in the book of the same title, Beijing sanlian shudian,

8. Chen Pingyuan, "Jin bai nian Zhongguo jingying wenhua de shiluo" (The decline of elite culturs, Ershivi shijit, June 1993 .

9. Wang Xiaoming et al., "Kuangye shang de feixu: wenxue he renwen jingshen de weiji" (Ruins in the desert: the crisis in culture and in the humanist spirit), Shanghai wenxue, No. 6, 1993.

10. Cai Xiang, Xu Jilin et al., "Daotong, xuetong, yu zhengtong" (Taoist orthodoxy, scholarly orthodoxy and orthodoxy), Dushu, No. 5, 1994.

11. Ibid.

12. Xu Jilin, "Renwen jingshen de duo yuan yiyi" (The multiplicity of meaning of the humanist spirit), Wenhuibao, Shanghai, December $17^{\text {th }} 1995$

13. See Chen Xiaoming, "Renwen guanhuai: yi zhong zhishi yu xushi" (The humanist concern: a form of knowledge and narration) Shanghai wenhud, No. 5, 1994. Zhang Yivu, "Renwen jingshen: Hebei zuojia bao, May $6^{\text {th }} 1995$.
Heist spirit: the last sacred word),

. Zhang Yiwu, "Xiandaixing de zhongiie: yige wufa huibi de keti" The end of modernity: a subject one cannot go back over),
Zhanglüe yu guanli, Peking, No. 4, 1994. Chen Xiaoming, "Houxiandai: wenhua de kuozhang yu cuowei" (Postmodernism: the expansion and false position of culture), Shanghai wenxue, No. 1994. Zhang Fa, Zhang Yiwu, Wang Yichuan, "Cong "xiandaixing" dao "zhonghuaxing "(From "modernity" to "sinity"), Wenyi zheng-

15. Zhang Fa et al,, "Cong 'xiandaixing' dao 'zhonghuaxing', ibid.

16. Cf. the author's: "Qimeng de mingyun", op. cit.

17. Cf. Zhang Rulun, Wang Xiaoming, "Renwen jingshen: shifou keeng he ruhe keneng (Is the humanist spirit possible and if

18. Cf. Zhang Chengzhi, Wuyuan de sixiang (Thoughts without help), Peking, Huayi chubanshe, 1995. Zhang Wei, Youfen de guitu ( $T$ he, 1995.

9. Cf. Wang Hui, Sihuo chongwen, Peking, Renmin wenxue chuban-

20. Cf. Antonio Gramsci, Prison Notebooks, translated by Cao Leiyu,

21. Cf. Michel Foucault, 'ÉEil du pouvoir, translated by Yan Feng,
Shanghai, Renmin chubanshe, p. 48, P. Shanghai, Renmin chubanshe, p. 48, p. 72 , and p. 147 .

22. When I call the critical intellectuals, embodied by Wang Hui, specific intellectuals of the Foucaldian type, it is only on the
basis of the similarities between their critiques, which seek to reveal unequal power relations. I thus overlook a fundamental difference between them: the specific intellectuals revealed by Foucault reject any global social objective, while cial justice and egalitarian power their objectives om, so cial justice and egalitarian power their objectives, and the op. cit, preface, p. 8 . 23. Jean-François Lyotard, "Tombeau de l'intellectuel", in Houxi-
andaixing yu gongzhong youxi (Post-modernity and public play), translated by Tan Yinzhou, Shanghai renmin chubanshe, Pp. 116117
24. Cf Jean-François Sirinelli, Intellectuels et Passion française, translated by Liu Yunhong, Jiangsu renmin chubanshe, 2001, p. 8; Pierre Bourdieu, "Le corporatisme de l'universel: le rôle des intellectuel dans le monde moderne, translated by Zhao Xiaoli, in Xueshu six-

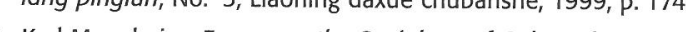
25. Karl Mannheim, Essays on the Sociology of Culture, in Kaer Manhaimu jingcui, translated by Xu Bin, Nanjing daxue chubanshe,

26. Pierre Bourdieu, Libre-échange, translated by Gui Yufang, Beijing

27. In particular by Jean-François Lyotard, La Condition postmoderne: rapport sur le savoir, translated by Che Jinshan, Beijing sanlian

28. Wang Xiaobo, Wo de jingshen jiayuan (The Native Country of My 2. Cf in particular Richard Posner Public ntellectuls A Sudy of

cline, translated by $X_{u} X_{i n}$, Zhongguo zhengfa daxu cha of De2002.

30. Wang Xiaobo, op. cit, preface, p. 3.

31. Cf. Chen Xuanliang, "Sate: you'an yu tongming zhijian" (Sartre: light and shadows), in Shiren zhexuejia, Zhong Guopin (ed.),
Shanghai renmin chubanshe, 1987, pp. 399-402.

32. Pierre Bourdieu, "Le corporatisme de l'universel", op. cit.

33. Jean-François Lyotard, "Tombean de l'intellectrl", op. cit.

34. Cf. Michel Foucault, "Intellectuels et pouvoir", dialogue avec Gilles Deleuze, in Fuke jii (A Foucault Anthology), Du Xiaozhen (ed.), Shanghai yuandong chubanshe, 1998.

35. Cf. Carl Boggs, Intellectuals and the Crisis of Modernity, translated by Li Jun and Cai Hairong, Jiangsu renmin chubanshe, 2002 pp. 208-217.

36. Michel Foucault, "Zhexue de shengming" (The life of philosophy), in LCEIl du pouvoir, translated by Yan Feng, Shanghai renmin chubanshe, 1997, p. 102.

. Cf. Michel Foucault, "Quanli yu xing" (Power and Sexuality), in LCEII du pouvoir, op. cit, p. 48.

38. Cf. Michel Foucault, "Quanli de chanshi" (Commentaries on power), in L'(Eil du pouvoir, op. cit, pp. 22-34.

30. Jürgen Habermas, Xiandaixing de zhexue huayu (The Philosophical Discourse of Modernity), Wang Minan, Chen Yongyuan and Ma Haillang (eds.), Zhejiang renmin chubanshe, 2000, p. 366.

40. Pierre Bourdieu never directly mentioned an ideal type of intellectual who from the specific moves towards the universal. What he put forvard was only the scientific intellectual of whom the ideal
type was the sociologist. However on the question of the public intellectual, which is our subject here, Bourdieu's theory offers in reality an ideal type of public intellectual which makes it possible to transcend the two conflicting models of the specific and the

41. Pierre Bourdieu, "Le corporatisme de l'universel", op. cit

42. Pierre Bourdieu, Libre-échange, op. cit, p. 72.

3. Pierre Bourdieu, "Le corporatisme de l'universel", op. cit.

\section{种州交统 \\ CHINESE CROSS CURRENTS}
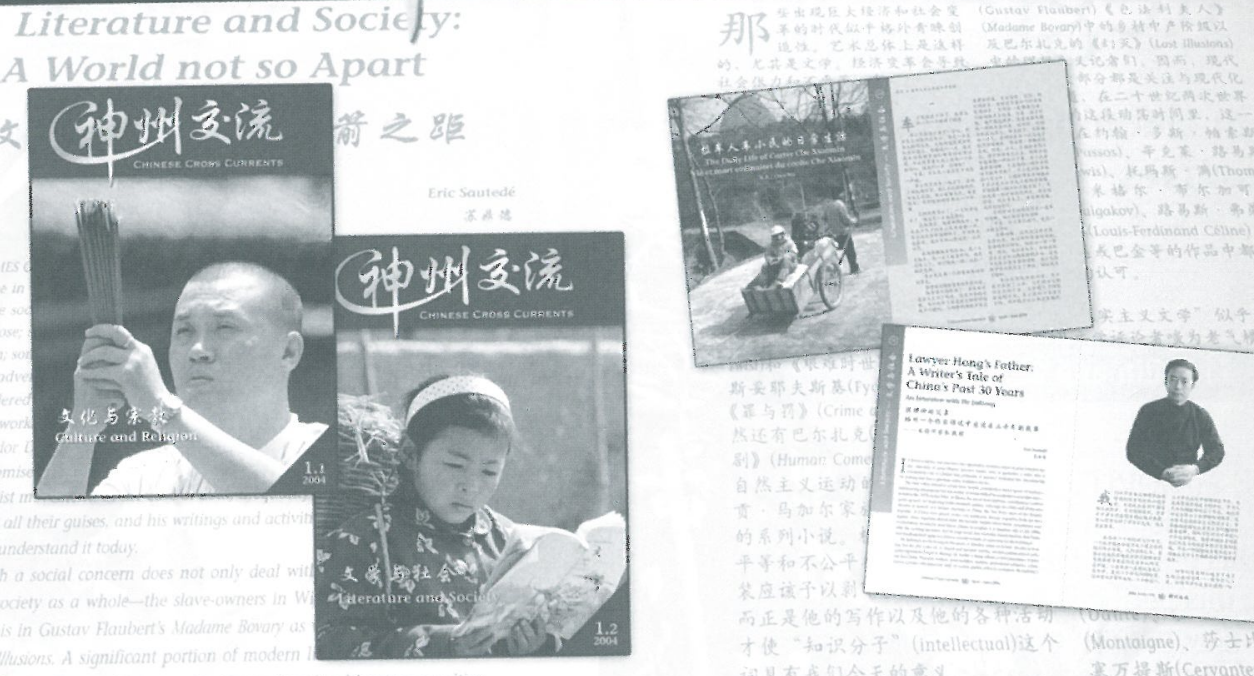

《神州交流》一份中英双语季刊，阔论当代中国的文化及社会

Chinese Cross Currents, a bilingual Chinese-English quarterly journal on issues pertaining to China's contemporary culture and society

未来的主题 Coming “Special Dossiers":

July-September 2004: 文化、艺术与社会—Culture, Art and Society

October-December 2004: 中国人: 人口问题一The Chinese: Demographic Issues

January-March 2005: 文化、法律与程序：中国与西方传统 Culture, Law and Order: Chinese and Western Traditions

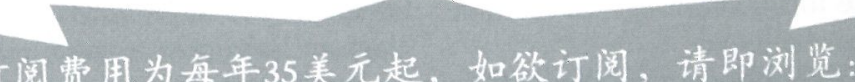

订阅费用为每年35美元起，如欲订阅，请即浏览: Www.riccimac.org/ccc

澳门荷兰园正街 95 号 $E$, 澳门利氏学社, 神州交流 Chinese Cross Currents, Macau Ricci Institute,

Avenida Conselheiro Ferreira de Almeida, No. 95-E, Macau (via Hong Kong) 电话 Tel: (853) 532536 传真 Fax to: (853) 568274 